Asian Fisheries Society, Manila, Philippines

Available online at www.asianfisheriessociety.org

\title{
Trophodynamics of the Spotfin Flathead Grammoplites suppositus (Troschel 1840) from the Southeast Arabian Sea
}

\author{
K.P. ABDURAHIMAN ${ }^{1}$, P.U. ZACHARIA ${ }^{2}$, T. H. NAYAK ${ }^{2}$ and \\ K.S. MOHAMED ${ }^{1^{*}}$ \\ ${ }^{1}$ Central Marine Fisheries Research Institute \\ P.B. No: 1603, Cochin- 682 018, Kerala State, India \\ ${ }^{2}$ Mangalore Research Centre, Central Marine Fisheries Research Institute \\ PO Box 244, Bolar, Mangalore 575001, Karnataka State, India
}

\begin{abstract}
The dietary habits of the spotfin flathead, Grammoplites suppositus which inhabits the southeast Arabian Sea was studied. The stomach contents of 581 specimens were analysed between September 2001 and May 2002. G. suppositus preyed primarily on crustaceans. The most important preys were benthic crabs and penaeid prawns, and fishes were next in rank. During premonsoon, fishes and crustaceans were equally important, whereas in monsoon and postmonsoon benthic crabs and penaeid prawns were the predominant prey. There were significant $(p<0.001)$ ontogenetic changes in the diet. Smaller length groups ( $<165 \mathrm{~mm}$ ) ate mostly the flatfish Cynoglossus macrostomus and other fishes, whereas individuals of larger length groups (>165 mm) ate crustaceans such as the benthic crabs, penaeid prawns, the paste shrimp, Acetes indicus and the mantis shrimp, Oratosquilla nepa. Highest similarity in diet was observed between 216240 and 241-265 mm length groups. Diet breadth was higher during the monsoon season; however, the trophic level which had a mean value of $3.79 \pm 0.13$ peaked during the postmonsoon season. Maximum diet breadth was for 191-215 mm length groups. The length of the prey Solenocera choprai had a linear positive correlation to the predator length $\left(r^{2}=0.72\right)$. Electivity studies showed that $G$. suppositus has a strong preference for low trophic level animals such as benthic crabs and Solenocera choprai. The Amundsen plot showed that $G$. suppositus is a specialized feeder on benthic crustaceans.
\end{abstract}

\footnotetext{
* Corresponding author. Tel. +91 484239 4867; Fax: +91 4842394909

E-mail address: ksmohamed@vsnl.com
} 


\section{Introduction}

Trophodynamic studies constitute the base for mass-balance models, which are increasingly being considered for the study and management of marine ecosystems (Robinson and Ware 1994; Pauly and Christensen 1995). Trophodynamics of flatheads or crocodile fishes inhabiting the Karnataka Coast of Southeast Arabian Sea has been investigated in the present study. Flatheads are benthic carnivorous fishes found on muddy or sandy bottoms of shelf areas at depths of about $75 \mathrm{~m}$ or less and are distributed throughout the tropical Indo-West Pacific region. The spotfin flathead, Grammoplites suppositus (Troschel 1840) is a common flathead exploited by the trawlers in the Bay of Bengal (Kapoor et al. 2002). This species is also exploited in the Arabian Gulf (Carpenter et al. 1997) and Sri Lanka (Kapoor et al. 2002). G. suppositus is an important species among the demersals exploited by Multi-day Fleet (MDF) trawlers and forms $2.11 \%$ (average annual catch $104.8 \mathrm{t}$ ) of the total catch of Karnataka State.

The specific aim of this study was to determine the most important prey and to examine how the ontogeny and season influence the feeding ecology and trophic level of G. suppositus. It also aimed to understand prey-predator relationships of flatheads which are particularly important in applying the ecosystem approach to fisheries management. As the role of predators in controlling lower trophic level populations has been observed as a major structuring factor in benthic marine communities (Shears and Babcock 2002), studies on the predator prey preference and feeding strategy were also conducted in order to identify potential impacts on prey populations of lower trophic levels.

A review indicates that study of diet of spotfin flathead is scanty. Brief description on the diet of allied species was given by Basheeruddin and Nayar (1961) and Rao (1964) on Grammoplites scaber and George et al. (1968) on Platycephalus maculipinna. Nasir (2000) observed the food and feeding relationship of $P$. indicus from inshore waters of Khor AlZubair, northwestern Arabian Gulf. The food and feeding ecology of $P$. indicus from Hong Kong (Wu 1984; Bauchot 1987) and Eastern Cape estuaries of South Africa (Marais 1984) were also studied. Studies by Paxton et al. (1989) on P. fuscus from Australia and Jeyaseelan (1998) on Cociella crocodila from Asian mangrove waters also outlined the basic feeding biology of flatheads. 


\section{Materials and Methods}

\section{Sampling}

Fish samples were collected from commercial catches of MDF trawlers operating from Mangalore and Malpe harbours along the coast of Karnataka in the Arabian Sea (between 11 ${ }^{0} 31^{\prime}$ and $15^{\circ} 45^{\prime} \mathrm{N}$ latitude and $73^{0} 30^{\prime}$ and $75^{\circ} 30^{\prime} \mathrm{E}$ longitude) during the period September 2001 to May 2002 (Fig. 1). Total lengths (TL) of $G$. suppositus were taken from the tip of

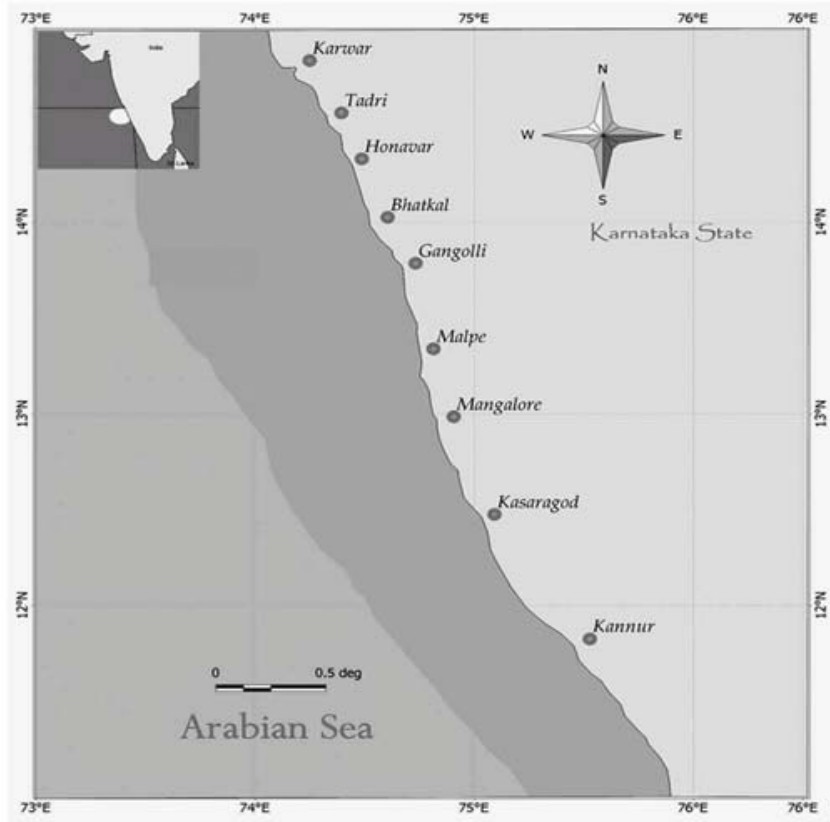

Fig.1. Map of the study area, showing major fishing harbours along Karnataka coast in the southeast Arabian Sea.

the snout to the tip of the caudal fin (mm) while weight measurements were taken to the nearest gram. After noting the TL and weight, the specimens were cut open to study the stomach condition and stomachs were preserved in 5\% formalin for diet analysis. A total of 581 stomachs were analysed to study the diet. Prey items were identified to the lowest taxon possible. Length, weight, count and displaced volume of each prey were determined.

\section{Data analysis}

The intensity of feeding was determined from the stomach distension and the amount of food it contained. When the stomachs were full it was considered as actively fed, $3 / 4$ full and $1 / 2$ full as moderately fed and $1 / 4$ full and traces were considered as poorly fed. The wet weight of the stomach contents was taken by using an electronic balance to the nearest mg. The Index of Relative Importance (IRI) was used to evaluate the importance of various food items found in the stomach as described by Pinkas et al. (1971): 


$$
I R I_{i}=\left(\% N_{i}+\% W_{i}\right) \bullet \% O_{i}
$$

where, $N_{i}, W_{i}$ and $O_{i}$ represent percentages of number, weight and frequency of occurrence of prey $i$ respectively. The IRI was expressed as 100\% (\%IRI) (Cortes 1997).

The diet data were grouped into $25 \mathrm{~mm}$ length groups (91-115, $116-140 \mathrm{~mm}$, etc.) to assess the changes in feeding and by season; monsoon (June-September), postmonsoon (October-January) and premonsoon (February-May) to study the seasonality in feeding. Although some authors (Balon 1986; Adriaens et al. 2001) described the ontogenetic diet shift of fishes (size related change in pattern of feeding) from the embryonic and larval stages, this present study critically studied only those length groups that appeared in the fishery (Manojkumar 2003; Figueiredo et al. 2005). Fishes of 91-115 and 116-140 mm length groups were excluded in the analysis due to insufficient sample size.

Levins (1968) index of diet breadth (Db) was calculated for respective length groups and seasons as a measure of degree to which all length groups use available resources in proportion to each other:

$$
D b=\frac{1}{\sum\left(p_{i j}{ }^{2}\right)}
$$

where, $p_{i j}$ is the proportion of resource state $j$ used by length group $i$. The index ranges from 0 (highly specialized) in which only a single resource is used, to $\mathrm{n}$ (highly generalized), where $\mathrm{n}$ is the total number of prey categories.

Trophic level (TrL) of the fish was calculated based on the proportion (by weight) of each prey components in the diet (Odum and Heald 1975):

$$
\operatorname{Tr} L=\sum\left(W_{i} T_{i}\right)+1
$$

where $W_{i}$ is the percentage by weight contribution of $i_{\text {th }}$ prey item and $T_{i}$ is the trophic level of the $i_{\text {th }}$ prey item. Trophic levels of different prey items were recorded from Fishbase (Froese and Pauly 2000).

To interpret predator feeding strategy, a graphical technique that relates prey abundance $\left(\mathrm{N}_{\mathrm{i}}\right.$ or $\left.\mathrm{W}_{\mathrm{i}}\right)$ to frequency of occurrence developed by Amundsen et al. (1996) was used. In the Amundsen plot, prey-specific abundance is plotted against frequency of occurrence, where prey-specific 
abundance $\left(\mathrm{P}_{i}\right)$ is defined as the proportion a prey item in only predators that contain prey $i$ and calculated as:

$$
P_{i}=\left(\sum S_{i} / \sum S_{t i}\right) \times 100
$$

where $P_{i}$ equals prey-specific abundance (numbers, mass or volume) of prey $i, S_{i}$ equals the abundance of prey in stomachs and $S_{t i}$ equals the total abundance of prey in predators that contain prey $i$. For the present study, proportion by weight of prey items was used to calculate preyspecific abundance.

In order to determine the selectivity, stomach samples were compared with their abundance in the environment using Ivlev's index of electivity (E) (Ivlev 1961) as:

$$
E=s-b / s+b
$$

where $s$ is percentage representation, by weight, of a food organism in the stomach; $b$ is percentage representation by weight, of the same organism in the environment. Positive values of electivity imply that the predator prefers the prey species or that it is feeding on prey species that occur in the environment. A value near zero implies no selectivity by the predator; i.e. the fish is feeding on the prey in proportion to the prey's relative abundance in the environment. Proportion of fishes and shellfishes in the trawl catch was used to calculate this index.

Non-parametric two-way contingency table analysis (Sokal and Rohlf 1995) was employed to test for independence between prey groups and seasons or length groups. To conduct this statistical test different prey categories were pooled into large categories such as fishes, prawns, crabs, other crustaceans and cephalopods. Bray-Curtis similarity coefficients were constructed to determine similarities in \%IRI among the seasons and different length groups using the software package PRIMER (Clarke and Warwick 2001).

\section{Results}

\section{General diet composition}

Out of 581 stomachs of $G$. suppositus (total length: 143-280 mm) analysed, a total of 21 prey types were identified. Mean number and 
weight of prey per stomach were 1.78 and 0.766 g respectively. Crustaceans (\%IRI= 86.9) and fishes (\%IRI=12.9) were the most important food categories of G. suppositus (Table 1). Molluscs, sea urchins and detritus were insignificant in the diet. When considering the frequency of occurrence, penaeid prawns (28.3\%), followed by benthic crabs $(26.4 \%)$ and unidentified fishes (16.0\%) were dominant. The most abundant prey by number was benthic crabs (27.9\%) followed by Acetes indicus (23.2\%) and S. choprai (16.2\%). In terms of weight, the benthic crabs (20.0\%) and S. choprai (19.7\%) were the prominent prey of G. suppositus. Among the fishes, unidentified fishes (15.2\%) and Nemipterus mesoprion (6.9\%) were largely consumed.

Table 1. Prey of G. suppositus in terms of frequency of occurrence (\%FO), gravimetric (\%W), numerical $(\% \mathrm{~N})$, and index of relative importance (IRI)

\begin{tabular}{lrrrrr}
\hline & \%FO & \%W & \%N & IRI & \%IRI \\
\cline { 2 - 6 } & & & & & \\
Prey Fishes & 1.12 & 6.98 & 0.78 & 7.30 & 0.27 \\
Nemipterus mesoprion & 0.74 & 0.72 & 0.39 & 0.70 & 0.03 \\
Grammoplites suppositus & 0.74 & 0.78 & 0.39 & 0.73 & 0.03 \\
Saurida spp. & 1.12 & 1.99 & 0.59 & 2.42 & 0.09 \\
Trichiurus spp. & 2.60 & 1.58 & 1.17 & 6.03 & 0.22 \\
Cynoglossus macrostomus & 0.37 & 0.09 & 0.20 & 0.09 & 0.00 \\
Stolephorus spp. & 1.12 & 1.06 & 0.78 & 1.73 & 0.06 \\
Leiognathus bindus & 2.97 & 1.41 & 3.52 & 12.34 & 0.46 \\
Fish juveniles & 15.99 & 15.19 & 8.40 & 317.90 & 11.80 \\
Unidentified fishes & & & & & \\
Crustaceans & 1.49 & 1.77 & 1.17 & 3.69 & 0.14 \\
Metapenaeus spp. & 2.97 & 3.66 & 1.76 & 13.58 & 0.50 \\
Trachypenaeus spp. & 13.01 & 19.70 & 16.21 & 855.44 & 31.76 \\
Solenocera choprai & 28.25 & 11.70 & 8.20 & 218.38 & 8.11 \\
Penaeid prawns & 6.32 & 2.55 & 23.24 & 137.47 & 5.10 \\
Acetes indicus & 26.39 & 19.96 & 27.93 & 1065.87 & 39.57 \\
Benthic crab & 1.12 & 0.43 & 1.17 & 1.51 & 0.06 \\
Hippa spp. & 5.20 & 7.18 & 3.52 & 46.94 & 1.74 \\
Oratosquilla nepa & & & & & \\
Miscellaneous items & 0.74 & 1.54 & 0.59 & 1.33 & 0.05 \\
Loligo spp. & 0.00 & 0.01 & 0.00 & 0.00 & 0.00 \\
Gastropods & 2.23 & 0.05 & 0.00 & 0.10 & 0.00 \\
Sea urchin & 4.09 & 1.67 & 0.00 & & 0.00 \\
Detritus & & & & & \\
\hline & & &
\end{tabular}

Among the crustaceans, \%IRI values for benthic crabs (39.6) and S. choprai (31.8) were higher. Penaeid prawns (8.1) and A. indicus (5.1) were the next in dominance among the crustaceans. Penaeid prawns such as Metapenaeus spp, Trachypenaeus spp and other crustaceans like Hippa spp and Oratosquilla nepa were also present. Among the fishes, unidentified fishes (11.8) were dominant followed by N. mesoprion, G. supposi- 
tus, Saurida spp, Trichiurus spp, Cynoglossus macrostomus, Stolephorus spp and Leiognathus bindus.

\section{Feeding intensity}

Fishes with empty stomachs were more throughout the season and the general diet of the fish was determined by the analysis of poorly fed fishes. The highest percentage of empty stomach was observed during the pre-monsoon (60\%). The proportion of fishes with active feeding condition was generally less though it showed an increasing trend from the monsoon to pre-monsoon seasons. With increase in length, the incidence of empty stomach was reduced although its proportion was high in all length groups. In general, occurrence of active feeding was less in all length groups. Fishes with moderate feeding intensity was more in the larger length groups and the difference was significant $\left(\chi^{2}\right.$ test, $\mathrm{df}=15$, $\mathrm{p}<0.001)$. The main source of variation in feeding intensities came from empty, poor and moderately fed fishes.

\section{Seasonal variations in feeding}

Prey shifting between crustaceans and fish items was obvious in all the seasons. Crustaceans formed more than $50 \%$ of the total IRI in all the seasons. In the premonsoon season, fishes (45.6\%) formed almost equally important diets as crustaceans (Table 2). Unidentified fishes (40.8\%) followed by S. choprai (30.9\%) and penaeid prawns (18.7\%) formed a major portion of the diet in the premonsoon season. During the monsoon season, a shift was observed and the most preferred prey was $S$. choprai (53.1\%); benthic crabs (38.4\%) being the second in importance. Benthic crabs (44.4\%) were the most important prey in the postmonsoon season followed by $A$. indicus (22.4\%) and $S$. choprai. There were significant seasonal differences $\left(\chi^{2}\right.$ test, $\left.\mathrm{df}=6, \mathrm{p}<0.001\right)$ in the number of major prey groups consumed. Among the prey groups the source of variation mainly came from other crustaceans (occurrence of large number of $A$. indicus in the postmonsoon season) and fishes.

Bray-Curtis similarity analysis grouped the seasons based on similarity (Fig. 2). The highest (68.2\%) was observed between the monsoon and postmonsoon seasons when flatheads preferred crustaceans.

\section{Ontogenetic variation in feeding}

The diet of G. suppositus of 141-165 mm length group comprised largely of unidentified fishes (\%IRI= 46.8) and C. macrostomus (\%IRI= 40.1) 
(Table 3). Fishes larger than $165 \mathrm{~mm}$ showed higher preference to crustaceans initially for $O$. nepa $(166-190 \mathrm{~mm})$ and later for $S$. choprai and benthic crabs. Cannibalism was found in 141-155 and 216-240 mm length groups. The preferred diets of fish of 216 to $240 \mathrm{~mm}$ were benthic crabs (\%IRI= 52.0) followed by S. choprai (\%IRI= 26.0) and penaeid prawns (\%IRI= 8.5). Consumption of benthic crabs and $S$. choprai increased to more than $166 \mathrm{~mm}$ in length and a consequent decrease in fish groups in higher length groups was observed. Significant ontogenetic differences were found $\left(\chi^{2}\right.$ test, $\mathrm{df}=20, \mathrm{p}<0.001$ ) in the number of major prey groups consumed. Among prey groups the major source of variation came from other crustaceans (occurrence of large number of $A$. indicus) and fishes.

Table 2. Seasonal variation in \%IRI of prey of G. suppositus

\begin{tabular}{lccc}
\hline \multirow{2}{*}{\multicolumn{1}{c}{ Prey }} & \multicolumn{3}{c}{ Seasons } \\
\cline { 2 - 4 } & Pre-monsoon & Monsoon & Post-monsoon \\
\hline Nemipterus mesoprion & 3.42 & 0.00 & 0.00 \\
Grammoplites suppositus & 0.00 & 0.24 & 0.00 \\
Saurida spp. & 0.14 & 0.03 & 0.00 \\
Trichiurus spp. & 0.00 & 0.00 & 0.42 \\
Cynoglossus macrostomus & 0.16 & 0.00 & 0.53 \\
Stolephorus spp. & 0.00 & 0.00 & 0.01 \\
Leiognathus bindus & 1.08 & 0.00 & 0.00 \\
Fish juveniles & 0.00 & 1.11 & 0.43 \\
Unidentified fishes & 40.81 & 5.67 & 1.43 \\
Metapenaeus spp. & 0.00 & 0.23 & 0.20 \\
Trachypenaeus spp. & 0.00 & 0.30 & 1.22 \\
Solenocera choprai & 30.91 & 53.11 & 12.41 \\
Penaeid prawns & 18.74 & 0.74 & 8.39 \\
Acetes indicus & 0.29 & 0.00 & 22.38 \\
Benthic crab & 3.68 & 38.36 & 44.43 \\
Hippa spp. & 0.00 & 0.13 & 0.04 \\
Oratosquilla nepa & 0.00 & 0.00 & 7.83 \\
Loligo spp. & 0.22 & 0.06 & 0.00 \\
Gastropods & 0.00 & 0.00 & 0.00 \\
Sea urchin & 0.00 & 0.01 & 0.00 \\
Detritus & 0.55 & 0.00 & 0.26 \\
\hline
\end{tabular}

Bray-Curtis similarity analysis between different length groups showed that 216-240 and 241-265 mm had the highest similarities (Fig. $3)$. These groups shared diets such as benthic crabs and prawns.

\section{Diet breadth and trophic levels}

In general, diet breadth was higher in the monsoon season than in the other seasons $(3.2 \pm 0.26)$. There was marginal increase in the trophic level values from the monsoon to postmonsoon and premonsoon seasons (Fig. 4). 


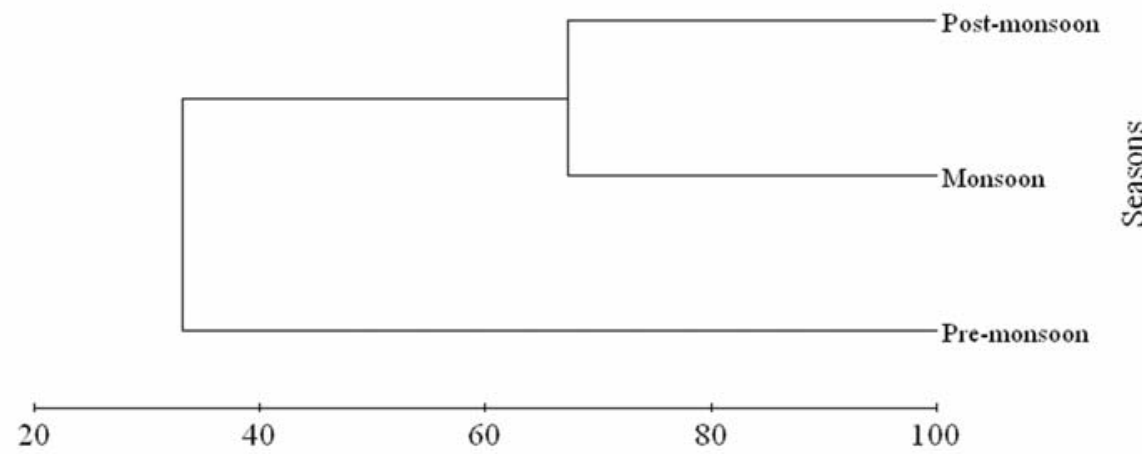

Bray-Curtis similarity

Fig. 2. Dendrogram of Bray-Curtis similarity of feeding among different seasons of $G$. suppositus

Table 3. Ontogenetic variation in \%IRI of prey of G. suppositus

\begin{tabular}{lcccccc}
\hline \multirow{2}{*}{\multicolumn{1}{c}{ Prey }} & \multicolumn{7}{c}{ Length groups (mm) } \\
\cline { 2 - 7 } & $141-165$ & $166-190$ & 215 & 240 & $241-$ & $266-$ \\
\hline Nemipterus mesoprion & 0.00 & 0.00 & 0.00 & 1.94 & 0.00 & 0.00 \\
Grammoplites suppositus & 3.94 & 0.00 & 0.00 & 0.07 & 0.00 & 0.00 \\
Saurida spp & 0.00 & 0.00 & 0.00 & 0.08 & 0.06 & 0.00 \\
Trichiurus spp & 0.00 & 2.78 & 0.12 & 0.00 & 0.00 & 0.00 \\
Cynoglossus macrostomus & 40.10 & 0.34 & 0.57 & 0.00 & 0.00 & 0.00 \\
Stolephorus spp & 0.00 & 0.28 & 0.00 & 0.00 & 0.00 & 0.00 \\
Leiognathus bindus & 0.00 & 0.00 & 0.35 & 0.00 & 0.08 & 0.00 \\
Fish juveniles & 0.00 & 0.00 & 0.05 & 0.20 & 3.60 & 0.00 \\
Unidentified fishes & 46.80 & 2.21 & 16.65 & 8.47 & 4.58 & 26.69 \\
Metapenaeus spp & 0.00 & 0.00 & 0.24 & 0.11 & 0.14 & 0.00 \\
Trachypenaeus spp & 0.00 & 0.00 & 1.44 & 0.13 & 0.74 & 0.00 \\
Solenocera choprai & 0.00 & 7.72 & 36.19 & 26.03 & 39.87 & 12.93 \\
Penaeid prawns & 0.00 & 4.85 & 4.10 & 8.47 & 9.83 & 21.09 \\
Acetes indicus & 0.00 & 0.00 & 7.44 & 1.88 & 2.06 & 39.29 \\
Benthic crab & 0.00 & 22.59 & 30.68 & 51.97 & 39.01 & 0.00 \\
Hippa spp & 0.00 & 0.00 & 0.00 & 0.47 & 0.00 & 0.00 \\
Oratosquilla nepa & 0.00 & 56.77 & 2.07 & 0.00 & 0.00 & 0.00 \\
Loligo spp & 0.00 & 1.38 & 0.00 & 0.05 & 0.00 & 0.00 \\
Gastropods & 0.00 & 0.00 & 0.00 & 0.00 & 0.00 & 0.00 \\
Sea urchin & 0.00 & 0.00 & 0.00 & 0.00 & 0.03 & 0.00 \\
Detritus & 9.16 & 1.08 & 0.10 & 0.13 & 0.00 & 0.00 \\
\hline
\end{tabular}




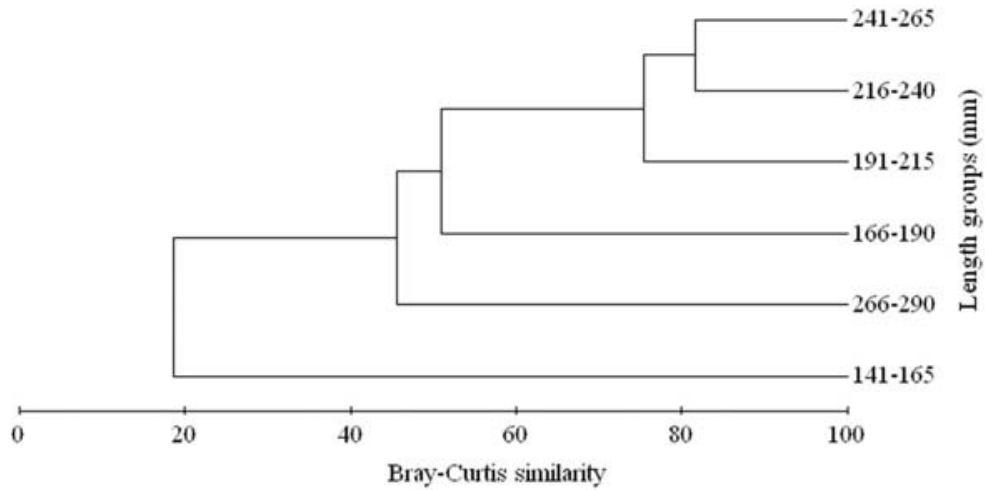

Fig. 3. Dendrogram of Bray-Curtis similarity of feeding among different length groups of $G$. suppositus

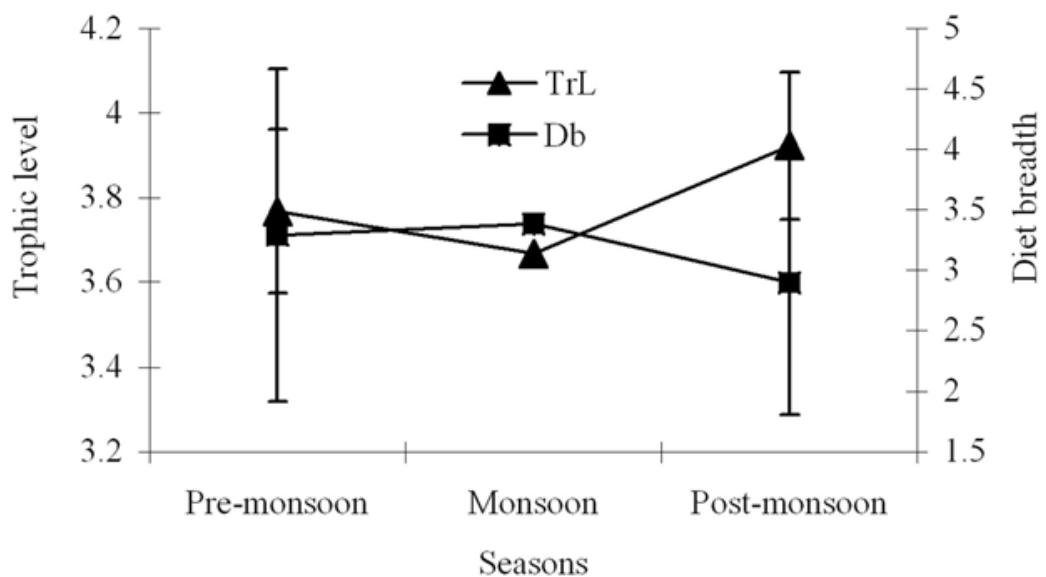

Fig.4. Seasonal variation in diet breadth and trophic level of G. suppositus 
The variation in diet breadth and trophic level among different length groups is shown in figure 5. The diet breadth increased with an increase in length up to 191-215 mm length group fishes. Beyond this length the range of prey reduced. The mean trophic level was $3.78 \pm 0.15$ and it increased from 141-165 mm to a peak in 166-190 mm and thereafter showed a decreasing trend.

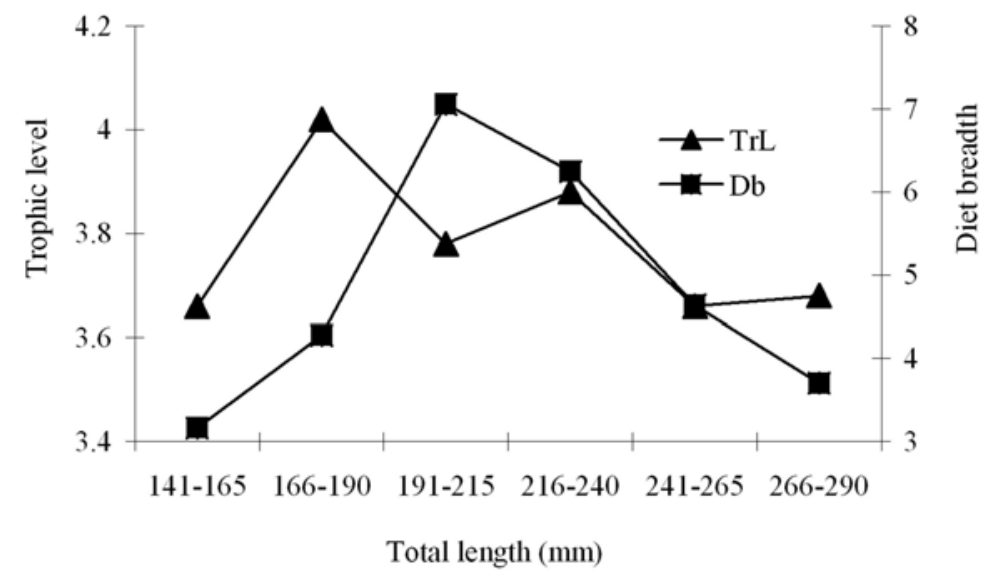

Fig.5. Ontogenetic variation in diet breadth and trophic level of G. suppositus

\section{Prey-predator relations}

It was evident that larger flatheads consumed larger benthic crabs (Fig. 6). Similarly, larger flatheads consumed larger prawns, S. choprai $(45.5 \pm 17.1 \mathrm{~mm})$. A distinct correlation was found between the total length of $S$. choprai and the body length of $G$. suppositus $\left(r^{2}=0.72, n\right.$ =17) (Fig. 7).

\section{Prey selection}

The values of electivity index showed that G. suppositus had strong positive selection to certain prey types in different seasons (Table 4). Changes in catch proportion in different seasons were reflected in fish diets and prey selection. However, crustaceans were strongly selected in all the seasons. Among crustaceans, strong selection for benthic crabs and S. choprai was observed in all the seasons. Penaeid prawns were strongly selected in the pre-monsoon and post-monsoon seasons though it was completely avoided in the monsoon season. Among fish groups, though Saurida spp formed good proportions in the fish catch, strong avoidance was observed for this group during the monsoon season. Moderate or poor 
selection was observed for N. mesoprion, Trichiurus spp., G. suppositus and other fishes although their species composition in the catch was high.

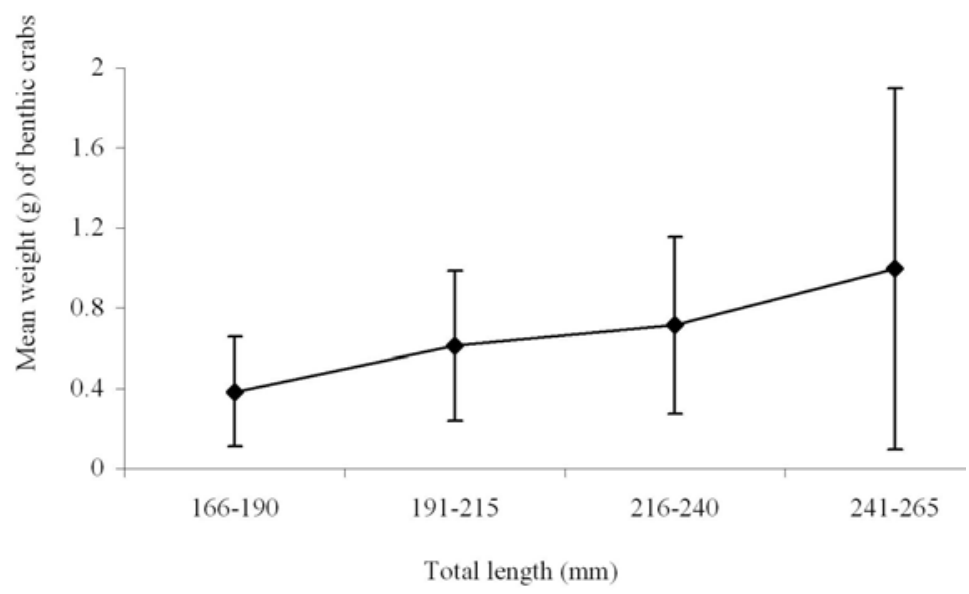

Fig. 6. Relationship between the weight of benthic crabs and the total length of $G$. suppositus

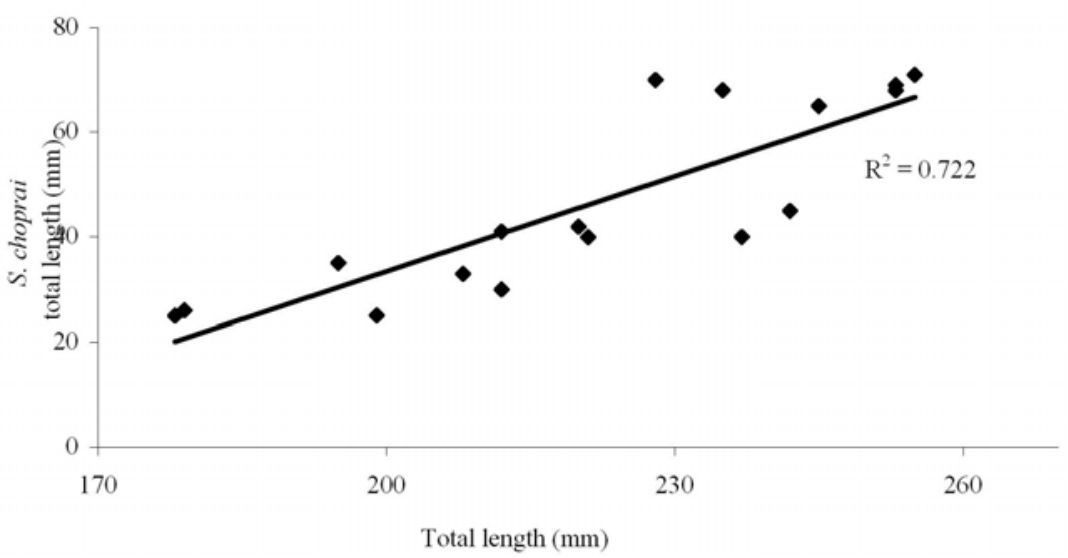

Fig. 7. Relationship between the total length of S. choprai and G. suppositus

\section{Predator feeding strategy}

The feeding strategy of G. suppositus was found by plotting prey-specific abundance against the frequency of occurrence (Fig. 8). There were 21 different prey types represented by points. The analysis showed that $G$. 
suppositus has a specialised feeding strategy focusing on crustaceans especially benthic crabs and penaeid prawns, which they consume in very large quantities.

Table 4. Seasonal electivity index of prey of G. suppositus

\begin{tabular}{lccc}
\hline \multicolumn{1}{c}{ Prey } & \multicolumn{3}{c}{ Seasons } \\
\cline { 2 - 4 } & Pre-monsoon & Monsoon & Post-monsoon \\
\hline Nemipterus mesoprion & 0.59 & - & - \\
Grammoplites suppositus & - & 0.18 & - \\
Saurida spp & 0.10 & -0.84 & - \\
Trichiurus spp & - & - & 0.67 \\
Cynoglossus macrostomus & 0.47 & - & -0.39 \\
Stolephorus spp & - & - & -0.75 \\
Leiognathus bindus & 0.50 & - & - \\
Fish juveniles & - & 0.78 & 0.87 \\
Unidentified fishes & 0.88 & 0.33 & 0.46 \\
Metapenaeus spp & - & - & 1.16 \\
Trachypenaeus spp* & - & - & - \\
Solenocera choprai & 0.86 & 0.77 & 0.68 \\
Penaeid prawns & 0.87 & - & 0.94 \\
Acetes indicus* & - & - & - \\
Benthic crab & 0.95 & 0.97 & 0.95 \\
Hippa spp* & - & - & - \\
Oratosquilla nepa & - & - & 0.73 \\
Loligo spp & -0.03 & 0.68 & - \\
Gastropods & - & -0.44 & - \\
Sea urchin* & - & - & - \\
Detritus* & - & - & - \\
\hline
\end{tabular}

*The Index could not be calculated since the percentage composition data of the group in the environment was not available.

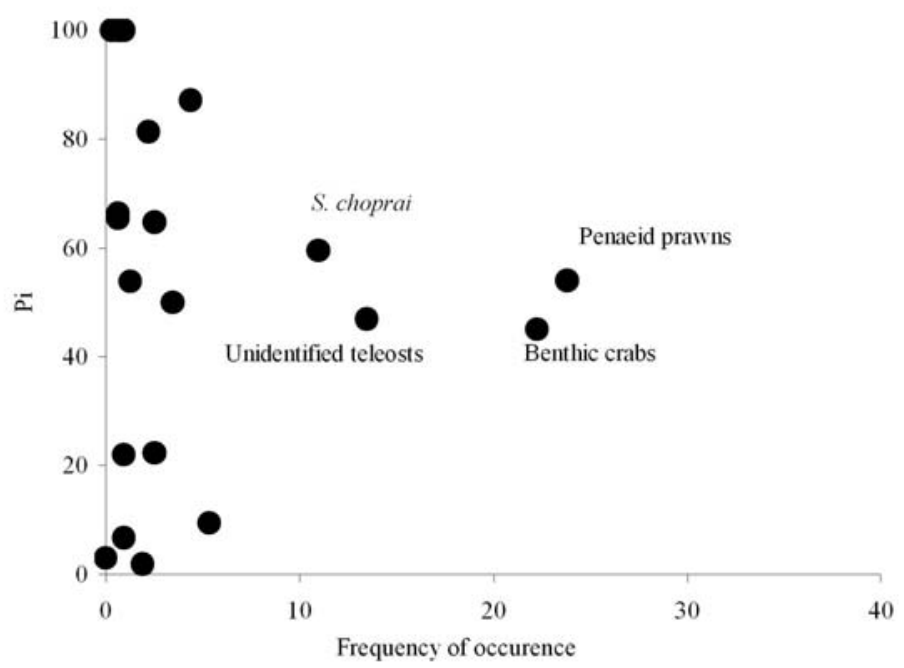

Fig. 8. Amundsen plot for $G$. suppositus showing prey-specific abundance $(\mathrm{Pi})$ 


\section{Discussion}

The spotfin flathead, G. suppositus is essentially a benthic predator feeding on crustaceans, teleosts, cephalopods and other miscellaneous items. The various components of the food spectrum indicate that the species is mainly a bottom feeder preferring low trophic level benthic crustaceans. The most preferred food were the benthic crabs and penaeid prawns, which are actively mobile in the substratum and therefore are hunted before the predator ingests them. The flat compressed body is designed for benthic mode of life. Teleost fishes such as N. mesoprion, G. suppositus, Saurida spp, C. macrostomus and $L$. bindus are demersal fishes inhabiting the bottom which form the food of $G$. suppositus agreeing with the benthic feeding behaviour. While studying $G$. scaber, Rao (1964) briefly described higher percentages of crustaceans followed by fishes in the diet. This agrees with the present study that crustaceans and fishes are the most important preys of flathead. Paxton et al. (1989) observed that in Platycephalus fuscus, small fish, crabs, prawns, small crustaceans, octopus, squid and polychaete worms were the major components in the diet. He observed that spines on the outer edge of their head can inflict deep cuts during handling of prey organisms.

In G. suppostius, penaeid prawns, dominated by S. choprai, formed the largest proportion by IRI and many other workers have also observed the importance of prawns in the diet of allied species. Nasir (2000) from Kuwait and Wu (1984) from Hong Kong reported that penaeid prawns formed the major food component of Platycephalus indicus. In G. suppositus fishes formed only a minor percentage in the diet. However, Marais (1984) while studying the feeding ecology of $P$. indicus from the Eastern Cape estuaries of South Africa observed that fish components, mainly Liza richardsoni formed the major proportion in the diet. Crabs were next in importance followed by a small fraction of other benthic crustaceans and algae. Bauchot (1987) identified crustaceans and fishes in the diet of P. indicus from Hong Kong waters. Jeyaseelan (1998) recorded unidentified fishes, shrimps and other benthic invertebrates as the most important diet of the similar species Cociella crocodila from Asian mangroves. In another species, P. maculipinna, George et al. (1968) reported that crustaceans were next in importance to fishes in its diet. Along with fishes and crustaceans, small quantities of polychaetes, gastropods and sea urchin spines were also found in this study. These studies indicate that in the northern latitudes particularly in Asia, crustaceans like crabs and prawns are the major components of the diet of flatheads followed by fishes. Conversely in the southern latitudes like the waters around South Africa, fishes are the principal component of the diet of flatheads followed by crustaceans. 
Diets of flatheads during the monsoon and post-monsoon seasons did not show much variation as a result of equal proportion of crustaceans in the diet. However, G. suppositus during the premonsoon season ate large quantities of fish groups along with crustaceans. This may be due to the changes in the food organisms and their availability (Nikolsky 1963). The present investigation also suggests that the nature of food of G. suppositus is size dependent. Fishes of smaller length groups $(<165 \mathrm{~mm})$ preferred mainly teleosts. Consumption of crustaceans was more in larger length groups indicating a significant shift in feeding preference. The Bray-Curtis similarity analysis showed that food of fishes of length 216-240 and 241-265 mm had highest similarity indicating a possible competition among length groups. However, Colwell and Futuyma (1971) have shown that a high value of diet overlap does not necessarily indicate competition. Food resources can often be shared amongst fish species or size classes of single species.

A large number of $G$. suppositus were found to have empty stomachs. The high percentage of the empty stomachs and poor feeding condition may be due to the spawning activity and seasonal variations in the availability of food. It may also be due to the fact that the sampling period and the feeding period of the day did not coincide. It has been reported that most carnivores are visual feeders which are known to feed during twilight hours (Jarre et al 1990). Kagwade (1972) recorded such occurrence of high percentage empty stomachs in many species of fishes from Bombay. The frequent occurrence of empty stomachs or stomachs with little contents may be probably dependent on the ratio between the size of the fish and the size of the prey (Allen 1935). Longhurst (1957) stated that when the fish is an important food item, the daily intake will be less because of the higher calorific value of the diet and as such empty stomachs will be more common.

Ontogenetically and seasonally the trophic level showed variations. The mean TrL of G. suppositus was $3.78 \pm 0.15$ and it did show deviation among the different length groups. In juveniles, low trophic level was recorded owing to the fact that the prey composition and diversity were less. Usually trophic level increases during ontogeny, because larvae and juveniles are likely to feed at lower levels than conspecific adults (Pauly et al. 2001). Hence there was a shift in trophic level in accordance with the ontogenetic diet shift. This is in agreement with studies of Cortes (1999) on elasmobranches. His results suggested positive correlation between trophic level and body length especially in carcharhinid sharks. However, as the size of flathead increases, trophic level also increased but in larger length groups it again decreased. This shift in trophic level with body length is in accordance with the view that trophic levels of aquatic organisms are inversely related to size (Pauly et al. 1998a). Darnell (1961) stated that animals of a given size and belonging to single species take food from several sources and ontogenetic progression of food habits is common 
in animals. However, for some fishes, ontogenetic shifts in diet are not always necessarily accompanied by an increase in trophic level. Trophic level failed to increase with increase in body size of lake trouts (Vander Zanden et al. 2000).

The existence of trophic level-body size relationship has implications for the numerous studies of food web pattern and dynamics that are based on body size (Cohen et al. 1993). In fitting mass balance models and evaluating fishing down food webs, the trophic level of each fish group is being used as an input by several authors (Pauly et al. 1998b; Vivekanandan et al. 2005). However, the term 'trophic level' in food web models is an operational term as the feeding habits and trophic levels of majority of fish groups are subjected to change depending on age, seasons, and availability of prey and the area of distribution (Vander Zanden and Rasmussen 1996; Cortes 1999; Figueiredo et al. 2005). Also, predators are typically larger than their prey and thus trophic level often increases with body size within a given food web (Cohen et al. 1993; Jennings and Mackinson 2003). This will result in a range of trophic level value for each fish group in the food web. Hence fitting mass balance models by using a constant trophic level may lead to erroneous results. Therefore, instead of fixing a constant trophic level, ontogenetic shift in trophic level of animals of a given size group belonging to a single species must be considered in massbalance ecosystem modelling studies.

In $G$. suppositus there is broad variation in the mean diet breadth among different length groups and seasons. Higher diet breadth in monsoon is attributed to the largest prey diversity and higher proportion of individual prey resources. This trend in the diet breadth with size may suggest that as the predator grows, it targets a new prey available to it together with the prey which it targeted at an earlier age. Darnell (1961) suggested that predators commonly utilize food resources according to their availability.

A positive linear relationship between lengths of predator and prey (S. choprai) was found. Likewise larger $G$. suppositus consumed bigger benthic crabs. Flavia et al. (2000) found in striped weakfish, Cynoscion guttucupa a positive linear trend for crustaceans, however, no relationship between the length of teleost prey and predator length was found. Coexisting fish species may differ in their morphology, feeding behavior and, to some extent, size-selection of prey species (Gibson and Ezzi 1987). A selection for small prey items, independent of predator size, has been recorded for many piscivorous fish under both laboratory and field conditions (Juanes and Conover 1994). They attest that this preference for small prey is a reflection of size-based attack success rates. Thus all sizes within predators mouth gape are attacked as encountered, but those most vulnerable are ingested most often, resulting in the apparent preference. Electivity study shows that $G$. suppositus strongly selected low trophic animals such as crustaceans mainly benthic crabs and penaeid prawns in the diet even though fishes formed the largest proportions in the demersal catch. This may also de- 
pend on the feeding ability of G. suppositus to eat large demersal and pelagic fishes available in the habitat.

The feeding strategy of the spotfin flathead was such that it most often showed a specialised feeding strategy on benthic crustaceans. These results support the theory proposed by MacArthur and Pianka (1996) that feeding will become more selective and specialised when food is abundant. This is again supported by the optimal foraging theory that predicts diets will become more specialised as the abundance of preferred prey increases (Pyke et al. 1977; Hart 1997).

\section{Acknowledgements}

We are indebted to the Director, Central Marine Fisheries Research Institute, Cochin and Dr C. Muthiah, Scientist-in-Charge of Mangalore Research Centre of CMFRI for providing the facilities and encouragement. This work was funded by the Indian Council of Agricultural Research (ICAR), New Delhi through a cess fund scheme on trophic modelling (064/004). We are also grateful to the staff of Mangalore Research Centre of CMFRI for their help in the field work. We would also like to thank Dr. E. Vivekanandan for the constructive criticisms to improve the manuscript.

\section{References}

Adriaens, D.P., P. Aerts and W. Verraes. 2001. Ontogenetic shift in mouth opening mechanism in a catfish (Clariidae, Siluriformes): A response to increasing functional demands. Journal of Morphology 247: 197-226.

Allen, K.R. 1935. The food and migration of the perch (Perca fluviatilis) in Windermere. Journal of Animal Ecology 4: 264-273.

Amundsen, P.A., H.M. Gabler and F.J. Staldvik. 1996. A new approach to graphical analysis of feeding strategy from stomach contents data - modification of the Costello method. Journal of Fish Biology 48: 607-614.

Balon, E.L. 1986. Types of feeding in the ontogeny of fishes and the life history model. Environmental Biology of Fishes 16: 11-24.

Basheeruddin, S and K.N. Nayar. 1961. A preliminary study of the juvenile fishes of the coastal waters of Madras City. Indian Journal of Fisheries 8:169-188.

Bauchot, M.L. 1987. Osseous Poisson. In: Cards FAO of identification for the needs for fishing, 891-1421. W. Fischer, M.L. Bauchot \& M. Schneider (eds). The Mediterranean \& Black Sea. Fishing Zone 37, EC and FAO, Rome.

Carpenter, K.E., F. Krupp, D.A. Jones and U. Zajonz. 1997. FAO species identification field guide for fishery purposes. Living marine resources of Kuwait, eastern Saudi Arabia, Bahrain, Qatar, and the United Arab Emirates. FAO, Rome. 
Clarke, K.R. and R.M. Warwick. 2001. Change in Marine Communities: An Approach to Statistical Analysis and Interpretation, 2nd Edition, Plymouth, Primer-E Ltd.

Cohen, J.E., S.L. Pimm, P. Yodzis, P and J. Saldana. 1993. Body size of animal predators and animal prey in food webs. Journal of Animal Ecology 62: 67-78

Colwell, R.K. and D.J. Futuyma.1971. On the measurement of niche breadths and overlap. Ecology 52: 567-576.

Cortés, E. 1997. A critical review of methods of studying fish feeding based on analysis of stomach contents: application to elasmobranch fishes. Canadian Journal of Fisheries Aquatic Sciences 54: 726-738.

Cortés, E. 1999. Standardized diet compositions and trophic levels of sharks. ICES Journal of Marine Science 56: 707-717.

Darnell, R.M. 1961. Trophic spectrum of an estuarine community based on studied of Lake Ponchartrain, Louisiana. Ecology 42:553-568.

Figueiredo, M., T. Morato, J.P. Barreiros, P. Afonso and R.S. Santos. 2005. Feeding ecology of the white seabream, Diplodus sargus, and the ballan wrasse, Labrus bergylta, in the Azores. Fisheries Research 75: 107-119.

Flavia, M., T.V. Lucena, J.R. Ellis and C.M. O’Brien. 2000. Seasonal variation in the diets of bluefish, Pomatomus saltatrix (Pomatomidae) and striped weakfish, Cynoscion guatucupa (Sciaenidae) in southern Brazil: implications of food partitioning. Environmental Biology of Fishes 57: 423-434.

Froese, R. and D. Pauly. 2000. FishBase 2000: Concepts, design and data sources. ICLARM, Los Banos, Laguna, Phillippines. 344 p.

George, K.C., M.G. Dayanandan and P.K. Nair. 1968. Food of some demersal fishes from the trawl grounds off Cochin. Indian Journal of Fisheries 15: 81-87.

Gibson, R.N. and A.I. Ezzi. 1987. Feeding relationships of a demersal fish assemblage on the west coast of Scotland. Journal of Fish Biology 31: 55-69.

Hart, P.J.B. 1997. Foraging tactics. In: Behavioural Ecology of Teleost Fishes (ed. G.J. JeanGuy), pp.104 -133. Oxford, Oxford University Press.

Ivlev, V.S. 1961. Experimental ecology of the feeding of fishes. Yale Univ Press, New Haven, 302 pp.

Jarre, A., M.L.D. Palomares, M.L. Soriano, M.L. Sambilay, V. Christensen \& D. Pauly. 1990. A user's manual for MAXIMS. (ICLARM Software 4), Int. Centre for Living Aquatic Resources Management, Manila, Philippines, 27 pp.

Jeyaseelan, M.J.P. 1998. Manual of fish eggs and larvae from Asian mangrove waters. United Nations Educational, Scientific and Cultural Organization. Paris. 193 p.

Jennings, S. and S. Mackinson. 2003. Abundance-body mass relationships in size-structured food webs. Ecology Letters 6: 971-974.

Juanes, F. and D.O. Conover. 1994. Piscivory and prey size selection in young-of-the-year bluefish: predator preference or size dependent capture success. Marine Ecology Progress Series 114: 59-69.

Kagwade, P. 1972. Food and feeding habits of Polynemus heptadactylus Cuv.and Val. Indian Journal Fisheries 16: 188-197.

Kapoor, D., R. Dayal and A.G. Ponniah. 2002. Fish biodiversity of India. National Bureau of Fish Genetic Resources, Lucknow, India, 775 p.

Levins, R. 1968. Evolution in changing environments: some theoretical explorations. Princeton University Press, Princeton, $120 \mathrm{p}$.

Longhurst, A.R.1957. The food of demersal fish of a West African estuary. Journal of Animal Ecology 26: 369-387.

MacArthur, R.H. and E. Pianka. 1966. On optimal use of a patchy environment. American Naturalist 100: 603-609.

Manojkumar, P.P. 2003. Observations on the food and feeding habits of Otolithes cuvieri (Trewavas) off Veraval. Indian Journal of Fisheries 50: 379-385 
Marais, J.F.K. 1984. Feeding ecology of major carnivorous fish from four Eastern Cape estuaries. South African Journal of Zoology 19: 210-223.

Nasir, N.A. 2000. The food and feeding relationships of the fish communities in the inshore waters of Khor Al-Zubair, northwest Arabian Gulf. Cybium 24: 89-99.

Nikolsky, G.V. 1963. The Ecology of Fishes. Moscow State University, Moscow. 263 p.

Odum, W.E. and E.J. Heald. 1975. The detritus-based food web of an estuarine mangrove community. In: Estuarine Research (ed. L.E Cronin), pp. 265-286. Academic Press, New York.

Paxton, J.R., D.F. Hoese, G.R. Allen and J.E. Hanley. 1989. Pisces. Petromyzontidae to Carangidae. Zoological Catalogue of Australia 7: 468-469.

Pauly, D. and V. Christensen. 1995. Primary production required to sustain global fisheries. Nature 374: 255-257.

Pauly, D., A. Trites, E. Capuli, and V. Christensen. 1998a. Diet composition and trophic levels of marine mammals. ICES Journal of Marine Science 55: 467-481

Pauly, D., V. Christensen, J. Dalsgaard, R. Froese. and F. Torres. 1998b. Fishing down marine food webs. Science 279: 860-863.

Pauly, D., L. Palomares, R. Froese, P. Sa-a, M. Vakily, D. Preikshot and S. Wallace. 2001. Fishing down Canadian aquatic food webs. Canadian Journal of Fisheries Aquatic Sciences 58: 51-62

Pinkas, L.M., S. Oliphant and I.L.K. Iverson. 1971. Food habits of albacore, bluefin tuna and bonito in Californian waters. California Fish and Game 52: 1-105.

Pyke, G.H., H.R. Pulliam and E.L. Charnov. 1977. Optimal foraging: a selective review of theory and tests. Quarterly Review of Biology 52: $137-153$.

Rao, K.S. 1964. Food and feeding habits of fishes form trawl catches in the Bay of Bengal with observations on diurnal variation in the nature of the feed. Indian Journal of Fisheries 11: 277-314.

Robinson, C.K. and D. Ware. 1994. Modelling pelagic fish and plankton trophodynamics off Southwestern Vancouver Island. British Columbia. Canadian Journal of Fisheries Aquatic Sciences 51: 1737-1750.

Shears, N.T. and R.C. Babcock. 2002. Marine reserves demonstrate top-down control of community structure on temperate reefs. Oecologia 132: 131-142.

Sokal, R.R. and F.G. Rohlf. 1995. Biometry. W.H. Freeman \& Co, New York.

Vander Zanden, M.J. and J.B. Rasmussen. 1996. A trophic position model of pelagic food webs: impact on contaminant bioaccumulation in lake trout. Ecological Monographs 66: 451477.

Vander Zanden, M.J., J.S, Brian, N.P. Lester and J.B. Ramussen. 2000. Within- and among population variation in the trophic position of a pelagic predator, lake trout (Salvelinus namaycush). Canadian Journal of Fisheries Aquatic Sciences 57: 725-731.

Vivekanandan, E., M. Srinath and S. Kuriakose. 2005. Fishing the marine food web along the Indian coast. Fisheries Research 72: 241-252.

Wu, R.S.S. 1984. The feeding habits of seven demersal fish species in a subtropical estuary. Asian Marine Biology 1, 17-26 